Thorax (1976), 31, 289.

\title{
Serological diagnosis of tuberculosis: a report of 12 months' clinical experience
}

\author{
A. C. N I CHOLL S a n K K H O R F I E L D
}

Midhurst Medical Research Institute, Midhurst, Sussex GU29 OBL

\begin{abstract}
Nicholls, A. C. and Horsfield, K. (1976). Thorax, 31, 289-293. Serological diagnosis of tuberculosis: a report of 12 months' clinical experience. This study reports the use of an agglutination test as a routine diagnostic aid for tuberculosis. We have found this to be both useful and reliable in clinical practice. The overall reliability was greater than $90 \%, 13$ false results being obtained in the 222 patients tested. False negatives (4) were less common than false positives (9). The major advantage of the test is its speed, serological diagnosis being available overnight as compared with an average of one month for diagnosis by culture.
\end{abstract}

The diagnosis of tuberculosis in many cases still poses a clinical problem and the need for more rapid diagnostic procedures has long been apparent. Many authors have reported serological tests which have appeared reliable when employed against sera from patients with known diagnoses (Middlebrook and Dubos, 1948; Parlett and Youmans, 1959; Takahashi, 1962; Lind, 1964; Duboczy and White, 1966; Wallace et al., 1966; Cole, Lazarus, and Hedrick, 1972; Affronti, Fife, and Grow, 1973; Nassau, Parsons, and Johnson, 1975; Nicholls, 1975) but none of these has proved of sufficient clinical usefulness to become universally adopted.

An initial study in this laboratory (Nicholls, 1975) has suggested that the agglutination test might be useful in the diagnosis of tuberculosis. In that study 168 of 171 control subjects gave negative serological results while 59 of 63 patients with culture-positive disease gave positive results. The purpose of the present study was to test the usefulness of the agglutination reaction in the clinical situation before a diagnosis had been made.

\section{MATERIAL AND METHODS}

During this period sera from 222 patients, in all of whom tuberculosis was a possible diagnosis, were examined. Sputum, cerebrospinal fluid, pleural fluid, urine and biopsy specimens taken for examination were subjected to microscopy for acid and alcohol-fast bacilli (AAFB) and were cultured on Lowenstein-Jensen slopes, prepared according to the recommendations of the International Union against Tuberculosis (Jensen, 1955). Cultures were incubated at $37^{\circ} \mathrm{C}$ and were examined weekly. Slopes showing no growth were retained for a minimum of 12 weeks. Serum for examination was separated by centrifugation from a $10 \mathrm{ml}$ venous blood sample. Serial samples were, where possible, taken at intervals of 7 to 10 days. Agglutination tests were carried out by the method previously described by Nicholls (1975). A rising agglutinin titre is defined in this study as a difference of two or more dilutions in the titres of serial samples.

\section{RESULTS}

The results of the initial agglutinin estimations on each patient are recorded in Table I. A positive serological result was one in which the agglutinin titre to Mycobacterium tuberculosis was $1 / 125$ or higher. The results are divided into five groups on the basis of serology and culture results. Group I consists of patients with both positive serology and culture results; group II, patients with both negative serology and culture results; group III, patients with negative serology but positive culture results; and group IV, patients with positive serology but negative culture results. Group V consists of patients who had positive culture results but from whom initial serum samples had agglutinin titres of less than 1/125. All of these patients had serial serum samples examined, and in all patients titres of $1 / 125$ or more were recorded in subsequent serum samples. 
T A B L E I

INITIAL AGGLUTININ TITRES AGAINST M. TUBERCULOSIS

\begin{tabular}{|c|c|c|c|c|c|c|}
\hline & Titre & $\begin{array}{l}\text { Group I } \\
\text { Culture Positive }\end{array}$ & $\underset{\text { Culture Negative }}{\text { Group II }}$ & $\begin{array}{c}\text { Group III } \\
\text { Culture Positive }\end{array}$ & $\begin{array}{c}\text { Group IV } \\
\text { Culture Negative }\end{array}$ & $\begin{array}{c}\text { Group V } \\
\text { Culture Positive }\end{array}$ \\
\hline Negative & $\begin{array}{r}<1 / 25 \\
1 / 25 \\
1 / 50\end{array}$ & E & $\begin{array}{l}96 \\
18 \\
31\end{array}$ & $\begin{array}{l}0 \\
0 \\
4\end{array}$ & E & $\begin{array}{l}0 \\
2 \\
5\end{array}$ \\
\hline Positive & $\begin{array}{l}1 / 125 \\
1 / 250\end{array}$ & $\begin{array}{l}21 \\
14\end{array}$ & 二 & $\overline{-}$ & $\begin{array}{r}15 \\
7\end{array}$ & 二 \\
\hline Total & $1 / 500$ & $\begin{array}{r}7 \\
42\end{array}$ & $1 \overline{45}$ & $\overline{4}$ & 24 & 7 \\
\hline
\end{tabular}

T A B L E I I

DETAILS OF PATIENTS IN GROUP I (CULTURE POSITIVE SEROLOGY POSITIVE)

\begin{tabular}{|c|c|c|c|c|}
\hline Diagnosis & No. & Age Range & $\begin{array}{l}\text { AAFB seen by } \\
\text { Microscopy }\end{array}$ & $\begin{array}{l}\text { No. with Rising } \\
\text { Agglutinin Titre }\end{array}$ \\
\hline $\begin{array}{l}\text { Pulmonary tuberculosis } \\
\text { Tuberculous meningitis } \\
\text { Tuberculosis of the spine } \\
\text { Renal tuberculosis } \\
\text { Total }\end{array}$ & $\begin{array}{r}37 \\
3 \\
1 \\
1 \\
42\end{array}$ & $\begin{array}{c}26-78 \\
23-37 \\
56 \\
53 \\
23-78\end{array}$ & $\begin{array}{r}26 \\
1 \\
0 \\
1 \\
28\end{array}$ & $\begin{array}{r}24 \\
3 \\
1 \\
1 \\
29\end{array}$ \\
\hline
\end{tabular}

Group I consists of 42 patients with tuberculosis, all of whom had titres of $1 / 125$ or more against $M$. tuberculosis (Table II). Thirty-six of these patients had two or more serum samples examined; 29 showed rising titres, the highest titre recorded being $1 / 2500$. In general, the titres recorded in extrapulmonary disease were lower than those seen in pulmonary disease. Mycobacteria were isolated in this group between 17 and 111 days (median 32 days) after inoculation of the Lowenstein-Jensen slopes. Positive serology results were obtained between 2 and 80 days (median 28 days) before positive culture results in 35 of the 42 cases. In the remaining seven cases, positive results from both serology and culture were obtained at the same time. AAFB were reported in smears from 21 patients, and eight of these reports preceded reports of positive serological results.

Group II consists of 145 patients with a variety of diseases (Table III) all of whom had titres of less than 1/125 in initial and subsequent serum samples. No patient demonstrated a rising titre. No positive cultures were obtained from specimens examined from patients in this group. AAFB were seen in one sputum smear from one patient with old tuberculosis but repeated attempts to obtain the organism by culture were unsuccessful.

Four patients from whom cultures were obtained gave false negative serology results (group III, Table IV). Three of these had pulmonary

\begin{tabular}{|c|c|c|}
\hline Diagnosis & No. & Age Range \\
\hline $\begin{array}{l}\text { Carcinoma of bronchus } \\
\text { Chronic bronchitis } \\
\text { Bacterial pneumonia } \\
\text { Viral pneumonia } \\
\text { Old TB routine investigation } \\
\text { Haemoptysis } \\
\text { Aspergillosis } \\
\text { Heart disease } \\
\text { Fibrosis } \\
\text { Bronchiectasis } \\
\text { Renal infection } \\
\text { Undiagnosed chest x-ray shadow } \\
\text { Total }\end{array}$ & $\begin{array}{r}29 \\
23 \\
25 \\
17 \\
10 \\
12 \\
4 \\
5 \\
3 \\
5 \\
9 \\
3 \\
145\end{array}$ & $\begin{array}{l}40-83 \\
40-83 \\
18-89 \\
29-84 \\
47-78 \\
21-72 \\
67-77 \\
57-74 \\
25-69 \\
25-63 \\
15-84 \\
24-35 \\
18-89\end{array}$ \\
\hline
\end{tabular}

T A B L E I V

DETAILS OF PATIENTS IN GROUP III (CULTURE POSITIVE SEROLOGY NEGATIVE)

\begin{tabular}{|c|c|c|c|c|}
\hline Patient & Sex & Age & Diagnosis & $\begin{array}{l}\text { No. of Sera } \\
\text { examined } 0\end{array}$ \\
\hline $\begin{array}{l}3 / 1 \\
3 / 2 \\
3 / 3 \\
3 / 4\end{array}$ & $\begin{array}{c}\mathbf{M} \\
\mathbf{M} \\
\mathbf{M} \\
\mathbf{F}\end{array}$ & $\begin{array}{l}72 \\
75 \\
78 \\
58\end{array}$ & $\begin{array}{c}\text { PTB } \\
\text { PTB } \\
\text { PTB } \\
\text { TB spine }\end{array}$ & $\frac{\text { CQ }}{\text { D }}$ \\
\hline
\end{tabular}

$\stackrel{0}{\stackrel{0}{\overparen{D}}}$

tuberculosis while one had tuberculosis of the spine. The three patients with pulmonary tubet culosis were all over 70 years of age and all four had titres of $1 / 50$. In one patient only one serum 
T A B L E V

DETAILS OF PATIENTS IN GROUP IV (CULTURE NEGATIVE, SEROLOGY POSITIVE AT 1/125)

\begin{tabular}{|c|c|c|c|}
\hline Diagnosis & No. & Age Range & $\begin{array}{l}\text { No. with Maximum } \\
\text { Titre of } 1 / 250 \text { or more }\end{array}$ \\
\hline $\begin{array}{l}\text { Carcinoma bronchus } \\
\text { Viral laryngitis } \\
\text { Recurrent tracheitis (history of pulmonary tuberculosis) } \\
\text { Asbestosis } \\
\text { Renal tuberculosis (histology) } \\
\text { Pulmonary tuberculosis (histology) } \\
\text { Pulmonary tuberculosis (clinical diagnosis) }\end{array}$ & $\begin{array}{l}6 \\
1 \\
1 \\
1 \\
1 \\
8 \\
6\end{array}$ & $\begin{array}{l}61-87 \\
48 \\
61 \\
57 \\
57 \\
49-83 \\
9-77\end{array}$ & $\begin{array}{l}1 \\
0 \\
0 \\
1 \\
0 \\
6 \\
4\end{array}$ \\
\hline
\end{tabular}

T A B L E V I

DETAILS OF PATIENTS IN GROUP V: POSITIVE CULTURE WITH INITIALLY NEGATIVE SEROLOGY RESULTS

\begin{tabular}{|c|c|c|c|c|c|c|c|}
\hline Patient & Age & Sex & Diagnosis & $\begin{array}{c}\text { Initial } \\
\text { Titre }\end{array}$ & $\begin{array}{c}\text { Subsequent } \\
\text { Highest } \\
\text { Titre }\end{array}$ & $\begin{array}{c}\text { No. of } \\
\text { First } \\
\text { Sample } \\
\text { Positive }^{1}\end{array}$ & Remarks \\
\hline $5 / 1$ & 57 & $\mathbf{M}$ & Pulmonary tuberculosis & $1 / 50$ & $1 / 250$ & 4 & Culture and direct ${ }^{2}$ smear positive before \\
\hline $5 / 2$ & 71 & $\mathbf{F}$ & Pulmonary tuberculosis & $1 / 25$ & $1 / 125$ & 3 & Smear positive 14 days before serology. \\
\hline $5 / 3$ & 38 & $\mathbf{F}$ & Renal tuberculosis & $1 / 50$ & $1 / 250$ & 3 & AAFB not seen in direct smear. Culture \\
\hline $5 / 4$ & 27 & $\mathbf{M}$ & Tuberculous meningitis & $1 / 50$ & $1 / 500$ & 2 & AAFB not seen. Culture positive on day of \\
\hline $5 / 5$ & 31 & $\mathbf{M}$ & Tuberculous meningitis & $1 / 50$ & $1 / 250$ & 2 & AAFB not seen. Culture positive 17 days after \\
\hline $5 / 6$ & 23 & $\mathbf{F}$ & Tuberculosis peritonitis & $1 / 25$ & $1 / 125$ & 2 & $\begin{array}{l}\text { Diagnosis confirmed by exploratory } \\
\text { laparotomy. Culture positive } 32 \text { days after }\end{array}$ \\
\hline $5 / 7$ & 22 & $\mathbf{F}$ & Tuberculous adenitis & $1 / 50$ & $1 / 250$ & 4 & $\begin{array}{l}\text { Diagnosis by histology } 7 \text { days before serology. } \\
\text { Culture positive } 3 \text { days before serology }\end{array}$ \\
\hline
\end{tabular}

Samples taken at 7-day intervals.

Dates of culture and positive smear not available.

sample was examined. The other three patients each had three serum samples examined. None showed any alteration in titre. All four yielded positive cultures-in one patient after 11 weeks' incubation.

Twenty-four patients had positive serology but failed to provide positive cultures (Table V). Definitive diagnoses other than tuberculosis were established in nine of the 24 cases, while a further nine were diagnosed as cases of tuberculosis, AAFB being seen in histological specimens. The remaining six were diagnosed as tuberculosis on clinical criteria and showed improvement with antituberculosis chemotherapy. In these six patients rising agglutinin titres were demonstrated within the first month of hospital admission in contrast with the non-tuberculous seropositive patients in whom titres remained static.

Group V consists of seven patients who had culture positive tuberculosis (Table VI). In five patients the initial agglutinin titre was $1 / 50$ while in the other two it was 1/25. All patients demonstrated a rising titre, which in five cases preceded the isolation of mycobacteria. Direct examination of sputum or biopsy material revealed AAFB or histological changes in four cases. In three cases this preceded the detection of a rising titre (Table VI).

\section{DISCUSSION}

In order that this study might reflect the usefulness of the agglutination test in the clinical situation, only patients in whom tuberculosis was considered in the differential diagnosis were included. In all but one case (patient 5/1) no diagnosis had been confirmed when initial serological investigations were requested. Of the 222 patients, 13 had serological results at variance with conventional culture, histology or clinical findings. False negative results were recorded in four patients (group II, Table IV) although these may have been a consequence of the failure to examine enough serum samples. False positive results were recorded in nine patients (group IV, Table V). Fifteen serologically positive diagnoses were without the support of a positive culture (group IV, Table V) and were treated as tuberculosis on the basis 
of histological (9) or clinical (6) findings. In total 61 patients were diagnosed as cases of tuberculosis: 57 were serologically positive while 46 yielded positive culture.

The most common differential diagnosis required was that between tuberculosis and carcinoma; this problem presented in 65 patients. Negative serological results were recorded in 32 cases. Agglutinin titres of $1 / 125$ or more were obtained in 33 patients, six of whom proved to have carcinoma. Postmortem examination of the mass from the only patient in this group who has died showed no involvement of old tuberculous glands. Comparable information is not available from the remaining five patients. In none of these six patients was a rising titre observed, and in five the titre recorded was $1 / 125$. In the 27 patients with tuberculosis none had a static titre at $1 / 125$ although three had static titres of $1 / 250$. The remaining three patients had chest radiograph shadows for which no explanation has been reached (Table III). These patients had negative serological results, failed to yield positive culture after 12 weeks, had no malignant cells in sputum examination, and had no significant findings at bronchoscopy. This serological test therefore reliably distinguished between carcinoma and tuberculosis in 56 of 62 cases where the differential diagnosis was required, and eliminated the probability of tuberculosis far earlier than conventional methods from three other cases where a diagnosis had still not been made.

The level of significance for the agglutinin titre $(1 / 125)$ was made in an earlier study (Nicholls, 1975 ) and the findings of this study have not indicated that this level should be altered. The raising of the significance level to $1 / 250$ would have eliminated 21 patients from group I (Table I) although the examination of subsequent samples would have reintroduced the 17 of these patients who had rising titres. It would also have eliminated 15 members of group IV, seven of whom had tuberculosis with rising titres. The nett effect would have been to delay the speed of diagnosis by up to three weeks while increasing reliability by only $1.5 \%$. This we do not consider to be useful for clinical practice.

A problem with all serological tests is that of reproducibility. An attempt was made to test the reproducibility of titre readings by retitrating known sera both in our own laboratory and in laboratories in other centres. At Midhurst 1000 retitrations of control sera have produced less than $1 \%(8)$ results at variance with original readings; none has varied by more than one dilution.
Titrations have also been undertaken by R. Sands (Selly Oak Hospital, Birmingham), Dr. R. Davies (St. Thomas Hospital, London), and Professō J. G. Cruickshank (Salisbury, Rhodesia); of 80 paired sera, 12 have given results at variance wit those obtained at Midhurst. Only one has varied by more than one dilution. The titre of this serurp was estimated as $1 / 1250$ in Rhodesia and as $1 / 125$. in Midhurst: the possibility of the sample havin been diluted 10 times before despatch has not beef excluded. On only one occasion has variatio meant the difference between a positive and negative result. In all cases antigen has been supt plied from Midhurst.

A rising agglutinin titre was observed in 29 group I patients, eight group IV patients, and seven group V patients; the initial titres in 32 of these patients were $1 / 125$ or less. The highes titre recorded in any patient was $1 / 2500$, five patients showing this level of antibody. The maxiv mum level seen in over half of the patients with rising agglutinin titres ( 25 of 44 ) was $1 / 500$; threg patients in group $\mathrm{V}$ and four patients in group demonstrated a maximum of $1 / 125$. Titres greate than $1 / 250$ have not been recorded in any perso 8 in whom tuberculosis has not been confirmed. A interesting product of these observations may be the possibility of a useful definition of active tuberculosis' as a disease process in which a rising agglutinin titre or an agglutinin titre of $1 / 250$. or more can be demonstrated against $M$ tuberculosis.

These results suggest that the agglutination test may be of clinical value in the diagnosis of tubers culosis, and it is difficult to explain why this test. should appear to work when many other more sophisticated techniques have proved less reliable? Perhaps the most significant factor has been the use of an antigen free from autoagglutination This has been achieved by treating the mycobac teria with sodium hydroxide (Nicholls, 1975) and allows the clear distinction between positive and negative reactions. It is also important that the agglutinin antibody is apparently not produced in response to BCG vaccination (Nicholls, unP published data) and that it is relatively shortlived in high titre after active primary or post-primar disease. In successfully treated active disease, titres are elevated (above 1/125) for between 6 and 180 months and are generally below $1 / 125$ at the ces sation of chemotherapy. The persistence of an elevated titre may indicate the need for furthe 8 therapy since three of four cases with titres of $1 / 125$ or more at the end of treatment have res lapsed within six months. It would seem that it 
the quantity of antibody present which is important since it is obvious that a large number of people have detectable levels of specific agglutinin in the apparent absence of mycobacterial disease.

We should like to thank Drs. Hunter and Tanner and the medical staff of King Edward VII Hospital, Midhurst for referring and following patients in this study, Lynda Robinson and William Lunt for skilled technical assistance, and Corinne Wade for preparing the manuscript. In addition we should like to thank Richard Sands, Dr. Robert Davies, and Professor Jan Cruickshank for titrating paired sera.

\section{REFERENCES}

Affronti, L. F., Fife, E. H., and Grow, L. (1973). Serodiagnostic test for tuberculosis. American Review of Respiratory Disease, 107, 822.

Cole, R. V., Lazarus, A. W., and Hedrick, H. G. (1972). Development and evaluation of a simple latex agglutination test for diagnosis of tuberculosis. Applied Microbiology, 24, 525.

Duboczy, B. O. and White, F. C. (1966). Latex agglutination test for tuberculosis. American Review of Respiratory Diseases, 94, 914.

Jensen, K. A. (1955). Second report of the Subcommittee of Laboratory Methods of the International Union against Tuberculosis. Bulletin of the International Union against Tuberculosis, 25, 89.
Lind, A. (1964). The gel double diffusion precipitation test in the diagnosis of tuberculosis. Bulletin of the International Union against Tuberculosis, 34, 37.

Middlebrook, H. and Dubos, R. J. (1948). Specific serum agglutination of erythrocytes sensitized with extracts of tubercle bacilli. Journal of Experimental Medicine, 88, 521.

Nassau, E., Parsons, E. R., and Johnson, G. D. (1975). Detection of antibodies to Mycobacterium tuberculosis by solid phase radioimmunoassay. Journal of Immunological Methods, 6, 261.

Nicholls, A. C. (1975). A serodiagnostic test for tuberculosis. Journal of Clinical Pathology, 28, 850.

Parlett, R. C. and Youmans, G. P. (1959). An evaluation of the specificity of gel double-diffusion test for tuberculosis. American Review of Respiratory Diseases, 80, 153.

Takahashi, Y. (1962). Specific serum agglutination of kaolin particles sensitized with tubercle phosphatide and its clinical evaluation as a serodiagnostic test for tuberculosis. American Review of Respiratory Diseases, 85, 708.

Wallace, R., Diena, B. B., Greenberg, L., and Jessamine, A. G. (1966). A study of tuberculosis antibodies by bentonite flocculation. Canadian Medical Association Journal, 94, 947.

Requests for reprints to: Dr. A. C. Nicholls, Midhurst Medical Research Institute, Midhurst, Sussex GU29 0BL. 